\title{
Hydrogel Leclanché Cell: Construction and Characterization
}

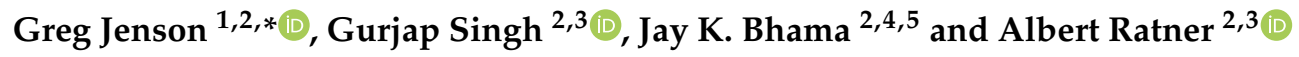 \\ 1 Department of Surgery, University of Iowa Hospitals and Clinics, Iowa City, IA 52242, USA \\ 2 Bhama-Ratner Artificial Heart \& MCS Advancement Lab, University of Iowa Department of Mechanical \\ Engineering, 3131 Seamans Ctr, Iowa City, IA 52242, USA; gurjap-singh@uiowa.edu (G.S.); \\ jkbhama@me.com (J.K.B.); albert-ratner@uiowa.edu (A.R.) \\ 3 Department of Mechanical Engineering, University of Iowa, Iowa City, IA 52242, USA \\ 4 Baptist Health Medical Center, Little Rock, AR 72205, USA \\ 5 Division of Cardiovascular Surgery, University of Arkansas for Medical Sciences, University of Arkansas for \\ Medical Sciences, 4301 W Markham, Little Rock, AR 72205, USA \\ * Correspondence: greg1.jenson1@gmail.com
}

Received: 10 December 2019; Accepted: 21 January 2020; Published: 28 January 2020

check for updates

\begin{abstract}
A liquid-to-gel based Leclanché cell has been designed, constructed and characterized for use in implantable medical devices and other applications where battery access is limited. This well-established chemistry will provide reliable electrochemical potential over a wide range of applications and the novel construction provides a solution for the re-charging of electrodes in hard to access areas such as an internal pacemaker. The traditional Leclanché cell, comprised of zinc (anode) and manganese dioxide (cathode), conductive carbon powder (acetylene black or graphite), and aqueous electrolyte $\left(\mathrm{NH}_{4} \mathrm{Cl}\right.$ and $\left.\mathrm{ZnCl}_{2}\right)$, has been suspended in an agar hydrogel to simplify construction while maintaining electrochemical performance. Agar hydrogel, saturated with electrolyte, serves as the cell support and separator allowing for the discharged battery suspension to be easily replaced once exhausted. Different amounts of active anode/cathode material have been tested and discharge characteristics have been plotted. It has been found that for the same amount of active material, acetylene black batteries have higher energy density compared to graphite batteries. Graphite batteries also discharge faster compared to acetylene black batteries. The results support further development of liquid batteries that can be replaced and refilled upon depletion.
\end{abstract}

Keywords: hydrogel; Leclanché; refillable; primary cell; liquid battery; liquid cathode; liquid anode; graphite; acetylene black; energy density

\section{Introduction}

The first implantable cardiac pacemaker was developed by Rune Elmqvist and implanted by Åke Senning in 1958 [1]. Many complications, such as leads and external hardware, associated with external pacemakers were now bypassed. This groundbreaking advancement inspired a collaborative effort to overcome the challenge to produce a reliable power supply for medical implants. However, internal pacemakers are still faced with the complications of reliable electrochemical power supply. When considering the design of batteries for implantable medical devices, additional challenges arise when evaluating battery chemistry for size, longevity, electrochemical performance, toxicity and most importantly how to recharge the electrochemical cell [2,3]. Today, various lithium ion and metal hydride technologies have significantly decreased the battery size while extending the battery lifetime yet, replacing the battery requires a surgical procedure that may result in further complications $[4,5]$.

Recent advances in battery chemistry have increased battery longevity. However, it was found that more than half of pacemaker recipients fully used their expected battery life, and the vast majority 
needed a replacement [6]. Although ideas such as rechargeable batteries have been explored in the past to bypass surgical battery replacement, these attempts were abandoned due to problems such as gas build-up during recharging [7] and patient non-compliance [4]. We propose an alternative approach to recharge the battery through the re-development of Leclanché electrodes. These battery components may be injected through a needle, simplifying the medical procedure and decreasing the risk to the patient.

In pursuit of this idea, we have used the Leclanché type chemistry to demonstrate the proof of concept of our liquid battery because this well characterized chemistry boasts high energy density and reliability $[8,9]$. In addition to favorable electrical characteristics, we have also evaluated the current state of battery and fuel cell technology. We believe that repurposing established battery technology exemplifies creativity, broadens the landscape for electrochemical possibilities, and serves to establish new methods to further electro-mobility [10-12]. This well-established chemistry has served as a reliable power source for more than a century and high-performance commercial batteries have been utilized in a variety of applications since the 1970s [13]. Although the precise electrochemical reactions at each electrode are controversial, a simplified electrochemical scheme is shown in Scheme 1 [14]. Recent studies regarding electrolyte composition, conductive additives, and new applications, such as flow batteries, demonstrate the relevance and applicability of the original Leclanché cell [15-17].

$$
\mathrm{Zn}_{(\mathrm{s})}+2 \mathrm{MnO}_{2(\mathrm{~s})} \longrightarrow \mathrm{ZnO}+\mathrm{Mn}_{2} \mathrm{O}_{3}(\mathrm{~s})
$$

Scheme 1. Simplified Leclanché cell electrochemical reaction.

The initial zinc carbon primary battery is known as the Leclanché cell and was developed over a century ago by a French telegraph engineer, Georges Leclanché [8]. Originally, these primary cells were formulated with zinc anode and manganese oxide cathode in combination with various conductive carbon powders saturated with an aqueous electrolyte. Later, Carl Gassner reconstructed these batteries with powdered or paste electrodes to develop the first "dry cell" battery. Dry cells are ideal for mobile applications that require intermittent discharge and variable spatial orientations, such as flashlights or radios, where leakage of liquid cells is detrimental. Today, the commercial Leclanché is housed in a cylindrical zinc container that encapsulates the separator, manganese-based cathode and a carbon rod current collector. Often, the mobile electrolytes, ammonium chloride and zinc chloride, are suspended in a separator such as: porcelain, paper or gelling agents such as starch. Modest cost, simplicity of production and favorable discharge characteristics have made this chemistry desirable for a variety of applications and has proven to occupy a significant portion of the market $[13,18]$.

In this research, the original Leclanché chemistry and battery construction has been simplified to be used in internal medical devices. Based on previous work by Jenson et al. [19], the electrodes have been suspended in an agar hydrogel to simplify the construction and replacement/recharging procedure of spent batteries. While under electrochemical load the hydrogel provides mechanical support allowing the battery to sample many spatial confirmations to maintain while maintaining electrochemical potential. The simplicity of the battery construction demonstrates the feasibility of the method to be used in a clinical setting.

Hydrogels are characterized by polymeric networks than can absorb a significant amount of water and become swollen granting new physical properties, such as physical stability and ionic conductivity [20]. Traditional applications of hydrogels include scaffolds for tissue regeneration, drug delivery or biochemical sensors due to their biocompatibility [21-23]. More recently, there has been an effort to expand the application scope of hydrogels to include flow reactors, waste remediation, and commodity chemical production [24-26]. Hydrogels as energy storage materials have seen recent interest and have been used in a variety of electronic devices such as capacitors, sensors, scaffolds for catalysis and electrode materials [27-30]. Excitingly, there has been some research and characterization of the zinc manganese oxide alkaline cell in gel form, but the application and reproducibility has yet to be demonstrated [31]. Additionally, our hydrogel battery features a straightforward construction 
because the hydrogel also serves as the separator allowing the entire battery hydrogel to be constructed in a simple container. Gel based separators are desirable because of high ionic conductivity, ability to form a variety of shapes and ease of fabrication [32]. Various carbohydrates binders and electro-spun modified agar have been reported for use as a battery separator however, we are not aware of literature reports using unmodified agar as a battery separator [33]. Due the instability of agar, we demonstrate the recharging of these electrochemical cells by treating the exhausted agar electrode matrix with warm aqueous acid to remove and replace the cell with new active material [34].

For a cardiac pacemaker or similar medical applications, we expect a much smaller form factor to be implanted into patients compared to the test cell used here. Since the battery is expected to be easily replaceable in a minor outpatient procedure, it can be made as small as required, especially for pediatric patients. We propose a final form factor as large as a small wristwatch/button cell to be the end goal of the fundamental research has been explored in this manuscript. Because of high contemporary interest in electrochemical power storage, new and better cell chemistries are being developed at an unprecedented rate. A refillable battery therefore makes it possible for higher power density and more biocompatible battery chemistry to be available to patients much earlier compared to traditional methods of surgical battery replacements.

\section{Materials and Methods}

\subsection{Design of Experiment}

The experimental setup has been designed to calculate the discharge rate of a given battery. The system can acquire analog data from a maximum of 16 data inputs in parallel and log it appropriately in a comma-separated values (.CSV) format (Figure 1). To calculate the discharge rate, a given battery is connected to a $10 \mathrm{k} \Omega$ resistor and is discharged across it until empty. Voltage across the resistor is measured using an acquisition card (more details in next section) at 30 min intervals.

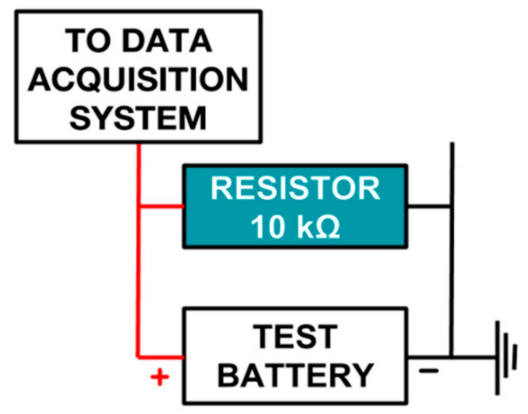

Figure 1. A single-battery test setup.

Plotting the voltage values of the battery at different points of time shows the required discharge trend line and helps compare different batteries. Once set, the experiment can simultaneously log data from a variety of batteries for weeks on end without intervention or supervision. The .CSV file generated by the system can then be used in a standard program like MS Excel or MATLAB ${ }^{\circledR}$ to generate data plots.

\subsection{Data Acquisition System}

The data acquisition system consists of an acquisition card and a data logger. The acquisition card used here is an Arduino ATMega 2560, which is an electronic microcontroller that can be programmed to acquire analog data from a maximum of 16 channels at any given interval. The signal range is from 0 to $5 \mathrm{~V}$, and the resolution is $4.9 \mathrm{mV}$ [35]. The acquired signal is sent via USB to a data logger, which is a Raspberry Pi 3 Model B running Raspbian. It is a Linux-based, single-board mini-computer. It can provide a graphic user interface (GUI) output to a computer screen via high-definition multimedia interface (HDMI), and peripherals like a keyboard and mouse can be plugged into it (Figure 2). The data 
logger runs a Linux-based version of Arduino. The acquisition card conditions the signal into a series of comma-separated values, which can be logged on to the Arduino Serial Monitor screen. These can be saved directly as a comma-separated value (.CSV) file.

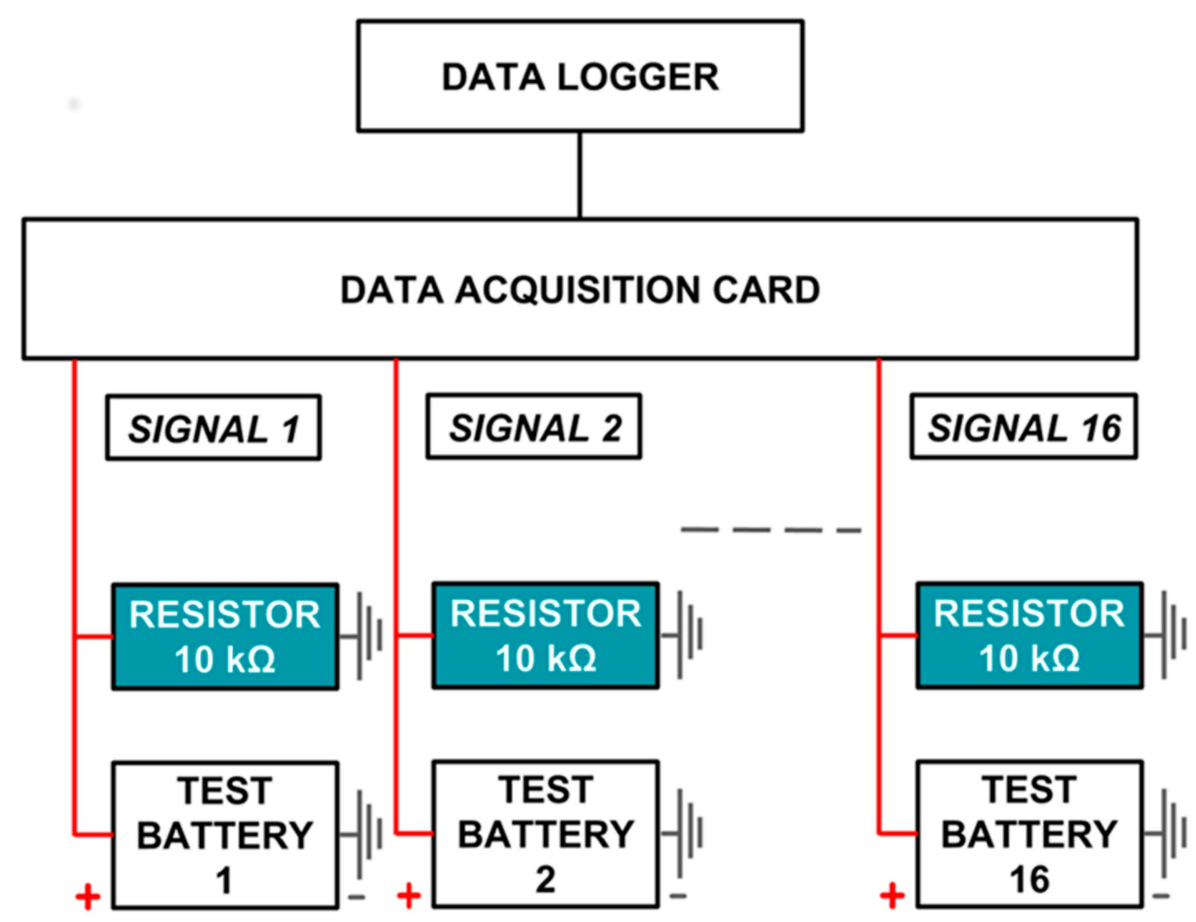

Figure 2. Schematic of data acquisition system.

\subsection{Gel Leclanché Cell Construction}

An Agar-Leclanché-graphite cell was constructed in a $20 \mathrm{~mL}$ vial by mass or volume of components. The electrolyte hydrogel was used at various points in the method and consists of the following by weight: $26 \% \mathrm{NH}_{4} \mathrm{Cl}$ (RPI, 99.5\%), 8.8\% $\mathrm{ZnCl}_{2}$ (Sigma, 98\%), 65.2\% de-ionized (DI) $\mathrm{H}_{2} \mathrm{O}$ and $1 \%$ w/v agar. This solution was heated to $90{ }^{\circ} \mathrm{C}$ until agar was dissolved and was then kept at $80{ }^{\circ} \mathrm{C}$. The electrolyte solution was the same as the electrolyte hydrogel minus the agar. The anode solution was constructed by the addition of $4 \mathrm{~g}$ Zn powder (Sigma, $10 \mu \mathrm{m}, 98 \%$ ), $2 \mathrm{~g}$ graphite powder (Sigma, $20 \mu \mathrm{m}$ ), and $6 \mathrm{~mL}$ electrolyte solution fallowed by vortex mixing until homogeneous. Then $3 \mathrm{~g}$ of the anode solution was transferred to a new vial with $3 \mathrm{~g}$ of a warm $\left(80^{\circ} \mathrm{C}\right) 1 \%$ w/v agar (RPI) electrolyte hydrogel and mixed by drawing the solution in and out of the syringe. It must be noted here that, since the distribution of conductive material plays a role in electrode conductivity [36], the mixing protocol for preparing the cathode and anode hydrogel was kept the same for each individual experiment. The anode hydrogel ( $3 \mathrm{~g}$ ) was then transferred to the electronic cell, via syringe, for battery construction and allowed to cool to room temp (RT) The warm $\left(80^{\circ} \mathrm{C}\right)$ agar separator hydrogel $(3 \mathrm{~g})$ was layered, via syringe, on the anode hydrogel, cooled to RT, followed by cathode hydrogel ( $3 \mathrm{~g})$. The cathode solution was constructed by the addition of $4 \mathrm{~g} \mathrm{MnO}_{2}$ (Sigma, 99\%), graphite $2 \mathrm{~g}$, and $6 \mathrm{~mL}$ electrolyte solution fallowed by vortex mixing until homogeneous. Then, $3 \mathrm{~g}$ of the cathode solution was transferred to a new vial with $3 \mathrm{~g}$ of a warm $\left(80{ }^{\circ} \mathrm{C}\right) 1 \%$ w/v agar electrolyte hydrogel and mixed by drawing the solution in and out of the syringe. The warm cathode hydrogel ( $3 \mathrm{~g})$ was then layered onto the hydrogel separator to complete the cell and cooled to RT. The $5 \mathrm{~mm}$ carbon electrodes (Eisco) were coated in paraffin (Gulf Wax) to span the cathode hydrogel and were submerged in the cell for characterization (Figure 3). Note that this cell was used for proof of concept only to demonstrate that liquid hydrogel-based chemistry worked in practice (Section 3.1). A later prototype was constructed with better purging capabilities for more extensive testing as reported in Sections 3.2 and 3.3. 


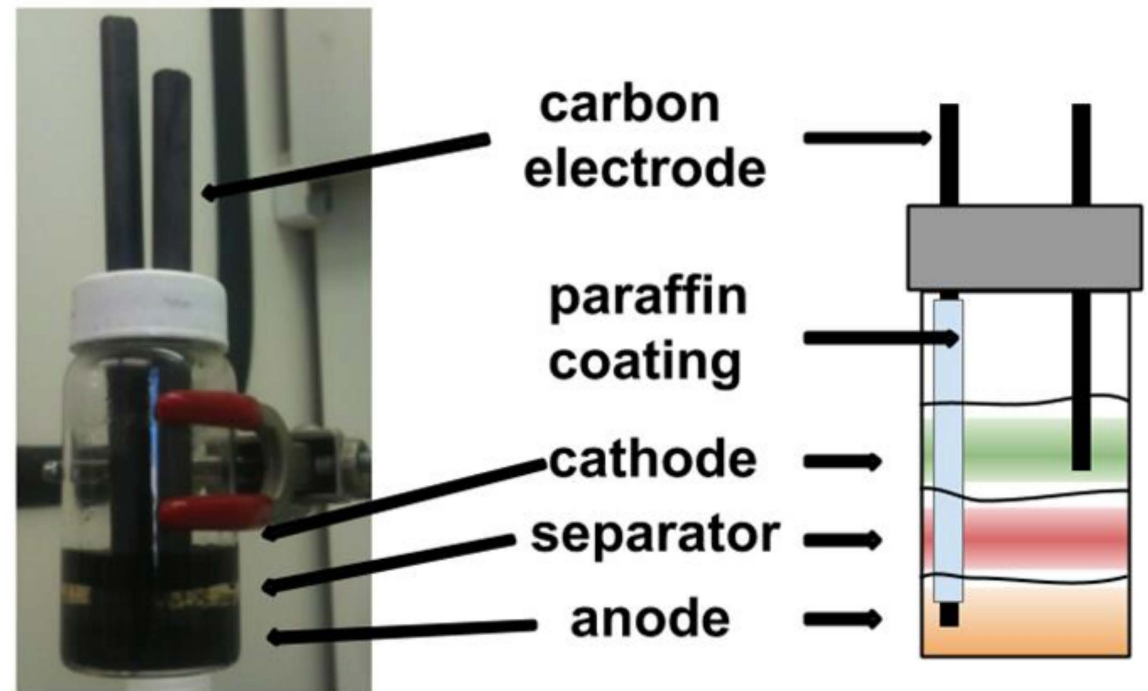

Figure 3. Gel Leclanché-graphite cell constructed in a $20 \mathrm{~mL}$ vial.

\subsection{Gel Leclanché Cells with Various Conductive Additives}

After the initial characteristics and experimental setup of the Zn agar cells were defined, the quantities of $\mathrm{Zn}$ and the identity of conductive additive were varied using a similar cell design. Please note the difference in mixing order, as we found this to make electrode construction easier. The anode hydrogel consists of $2 \mathrm{~g}$ saturated conductive additive electrolyte solution (1.5 g acetylene black or graphite and $20 \mathrm{~mL}$ electrolyte solution), $1 \mathrm{~g}$ warm $\left(80^{\circ} \mathrm{C}\right)$ agar electrolyte hydrogel $(2.5 \% \mathrm{w} / \mathrm{v})$ with $0.25,0.5$ or $0.75 \mathrm{~g} Z \mathrm{Zn}$ powder and mixed by syringe. The anode hydrogel ( $3 \mathrm{~g})$ was transferred to the glass vial for cell construction and allowed to cool to RT. Warm $\left(80^{\circ} \mathrm{C}\right)$ agar electrolyte separator ( $3 \mathrm{~g})$, as discussed previously, was layered on the anode and allowed to cool to RT. The warm $\left(80^{\circ} \mathrm{C}\right)$ cathode hydrogel was layered on the separator and cooled to RT. The cathode hydrogel consists of $2 \mathrm{~g}$ of the saturated conductive additive electrolyte solution (1.5 g acetylene black or graphite and $20 \mathrm{~mL}$ electrolyte solution), $1 \mathrm{~g}$ warm $\left(80^{\circ} \mathrm{C}\right)$ agar electrolyte hydrogel $\left(2.5 \%\right.$ w/v) with $0.5 \mathrm{~g} \mathrm{MnO}_{2}$ and mixed by syringe. As previously described, $0.5 \mathrm{~mm}$ carbon electrodes coated in paraffin to span the cathode were used as current collectors (Figure 3).

\subsection{Closed Leclanché Gel Cell Construction and Purging}

A gel Leclanché cell with better purging characteristics was constructed in an $11 \mathrm{~mL}$ glass chamber equipped with purge/fill ports and current collection ports (Figure 4). Please note the difference in electrode composition and mixing-this was optimized for the purge and refill procedure, not the electronic characteristics. The gel anode and cathode consist of $0.5 \% w / v$ agar dissolved in 3 $\mathrm{mL}$ (1:1) electrolyte solution: ethylene glycol (Sigma) with 0.1g acetylene black and $0.25 \mathrm{~g} \mathrm{MnO}_{2}$ or $\mathrm{Zn}$. All components were added together, then heated briefly $\left(90{ }^{\circ} \mathrm{C}\right)$ and mixed by syringe as previously described. The gel separator consists of $0.25 \% w / v$ agar dissolved in aqueous electrolyte and ethylene glycol hydrogel (1:1) by heading $\left(90^{\circ} \mathrm{C}\right)$ and was mixed by syringe. Each layer was allowed to cool to RT prior to the addition of the next. The cathode hydrogel was layered first, followed by the separator and, finally, the anode hydrogel. The spent hydrogels were removed by treating the cell with warm acidic water $(\mathrm{pH} \sim 1)$ until clean, and the next Leclanché gel components were constructed and layered as previously described. 


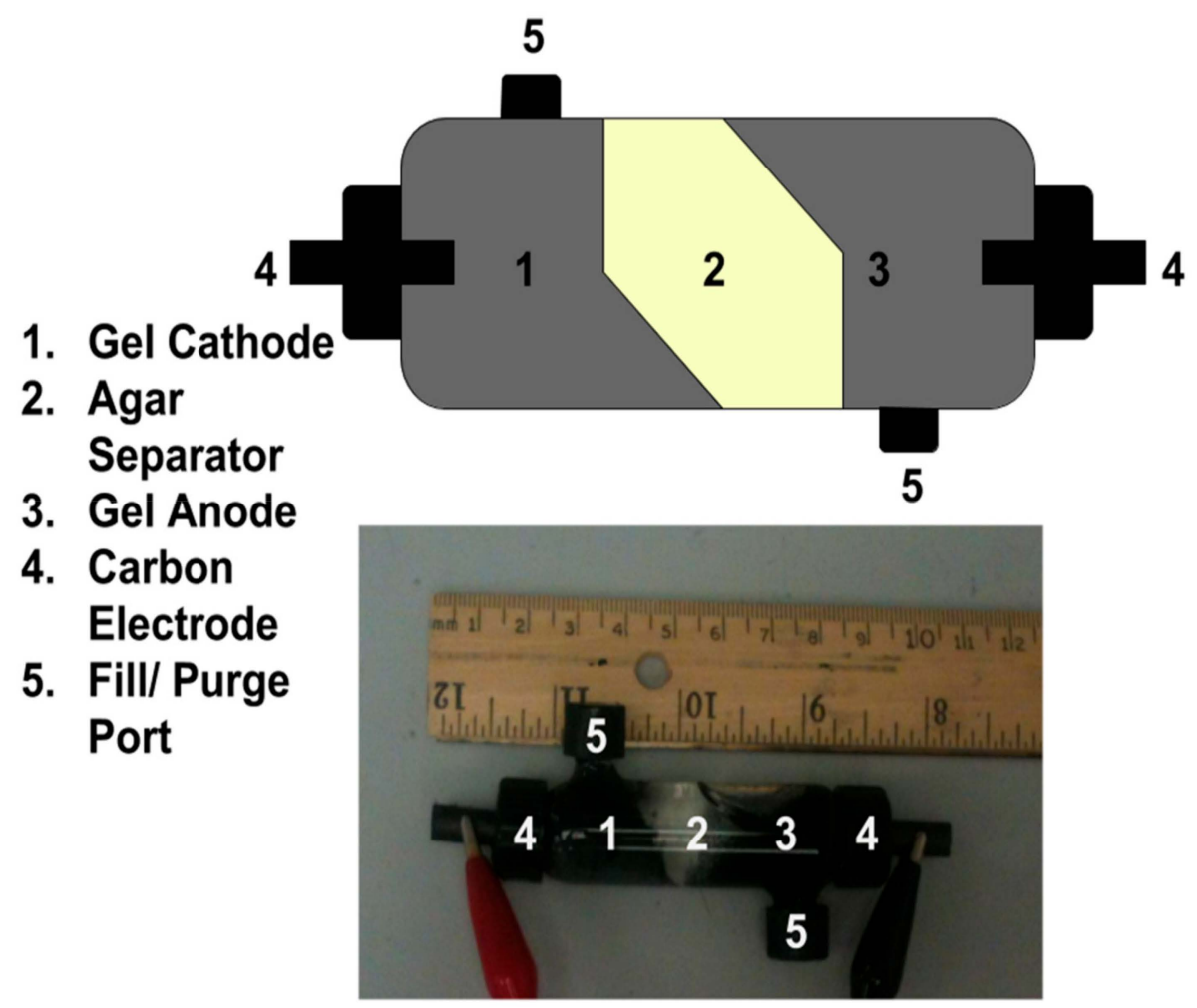

Figure 4. Closed gel Leclanché cell construction in an $11 \mathrm{~mL}$ glass chamber with ports for purge/filling and ports for current collection.

\section{Results}

\subsection{Gel Leclanché Cell: Proof of Concept}

A proof of concept hydrogel battery (Figure 3) was constructed using graphite (GR), and average discharge characteristics of three trials are shown in Figure 5. Each cell was characterized by recording the voltage under a $10 \mathrm{k} \Omega$ load every 30 min until the cell potential reached a constant reading $(\sim 0.1 \mathrm{~V})$. There was an initial rapid drop in potential $(0-50,000 \mathrm{~s})$ followed by a period of stabilization $(50,000-240,000 \mathrm{~s})$ until the final rapid discharge (Figure 5). This proved that hydrogel-based anodes and cathodes, when separated with a hydrogel-based conductive separator, could provide a sustained voltage for a substantial period of time. Another glass cell was thereafter constructed (Figure 4) which could be easily purged. This cell was used in Sections 3.2 and 3.3 for construction and characterization of other Leclanché cells.

\subsection{Different Conductive Additives}

Leclanché hydrogel batteries constructed with acetylene black $(\mathrm{AB})$ as the conducting additive display slightly enhanced characteristics under continuous discharge than batteries constructed with graphite (GR). Open circuit voltages (OCVs) were measured with a multimiter to characterize the cell potential on construction. Closed circuit potentials (CCVs) were measured using the Arduino as described in Sections 2.1 and 2.2. OCVs are taken on cell construction to establish the upper limit of each battery potential and the CCVs are taken at defined intervals, while the battery remains under the load of the resistor to generate the discharge curves. Initial OCVs, irrespective of the zinc quantity, in each cell are greater in cells constructed with acetylene black than cells constructed with GR $(\sim 1.15 \mathrm{~V}$ vs. $\sim 0.75 \mathrm{~V})$. Additionally, the $\mathrm{AB}$ cell produces a nearly constant CCV of $\sim 1.05 \mathrm{~V}$ from time zero until approximately $8000 \mathrm{~s}$ in cells constructed with 0.5 and $0.75 \mathrm{~g}$ zinc powder. Beyond $0.5 \mathrm{~g}$ zinc powder, there is not a significant difference in the cell lifetime (Figure 6). 


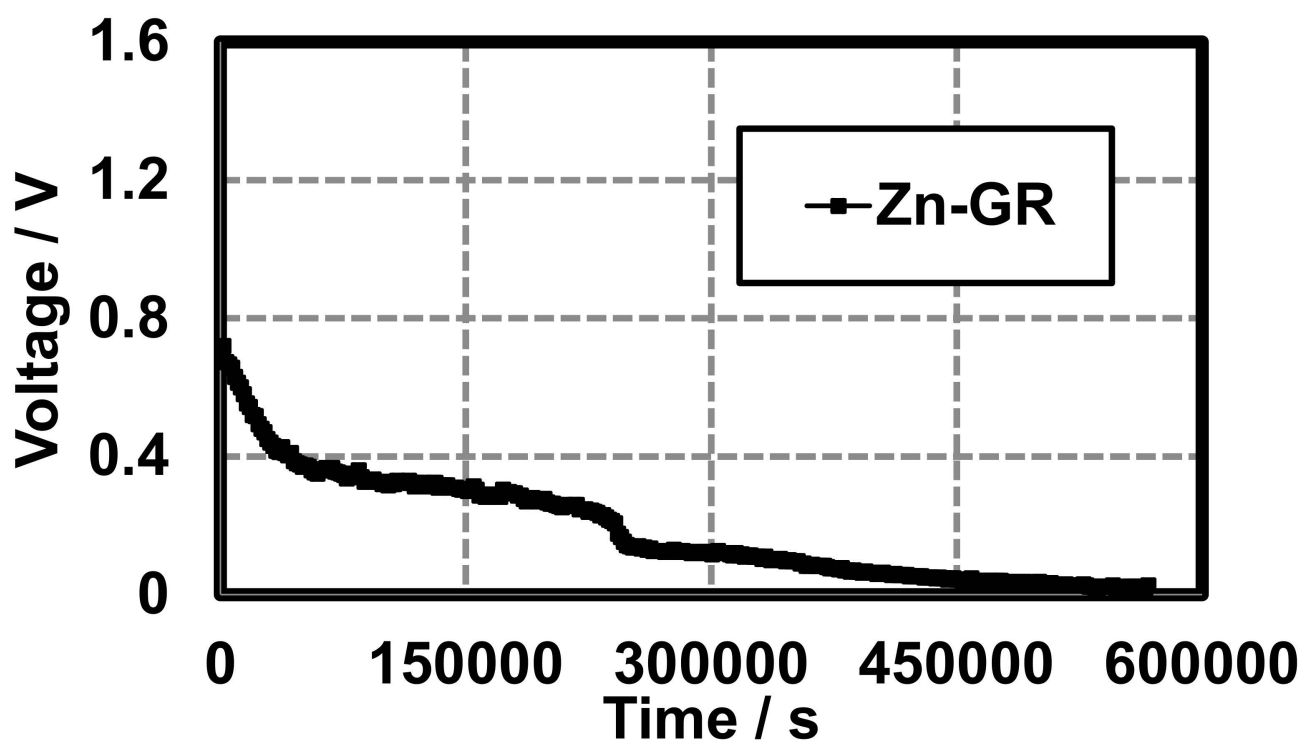

Figure 5. Gel Leclanché cell continuous discharge data across a $10 \mathrm{k} \Omega$ resistor with $\mathrm{GR}$ as the conductive additive. Average of three trials.

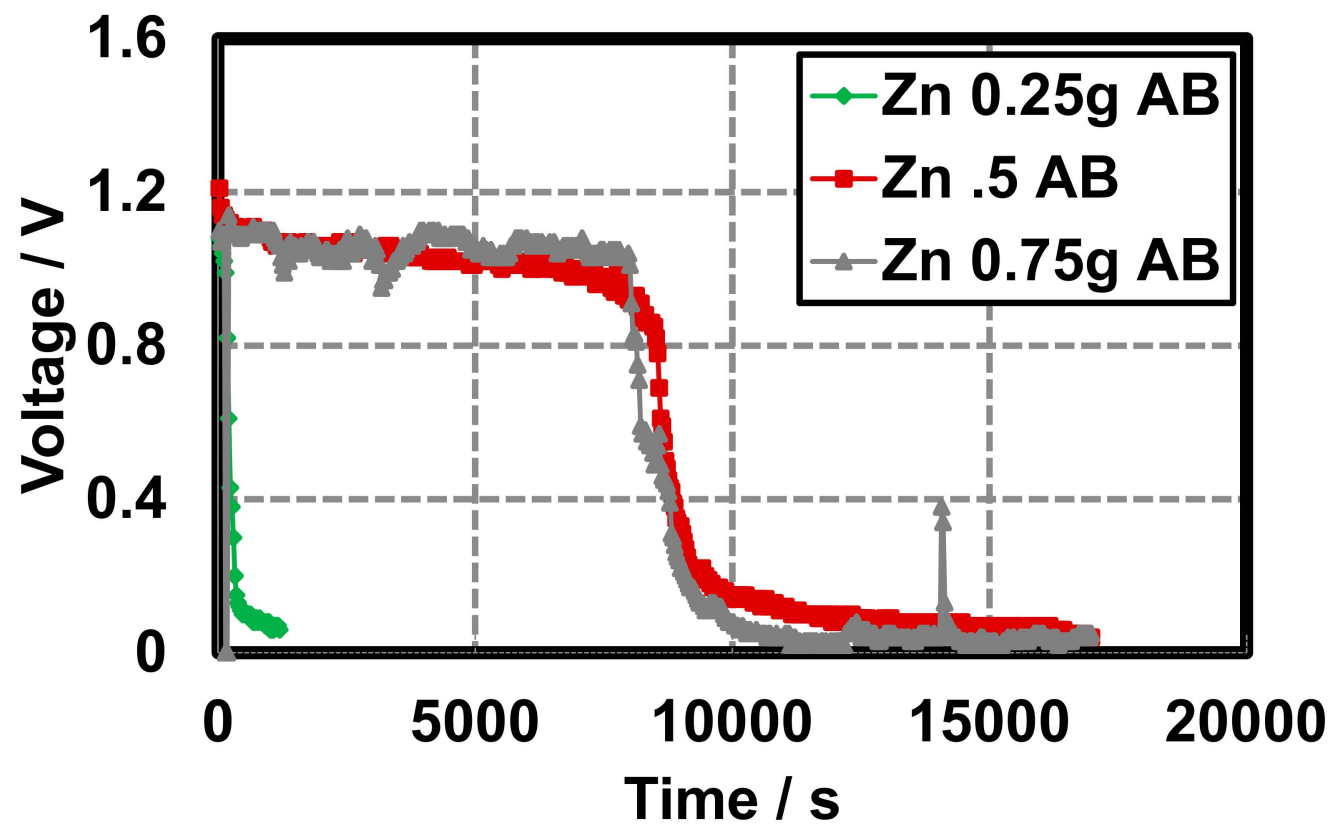

Figure 6. Gel Leclanché cell continuous discharge data across a $10 \mathrm{k} \Omega$ resistor, with $\mathrm{AB}$ as the conductive additive, $0.5 \mathrm{~g} \mathrm{MnO}_{2}$, and variable zinc: $0.25 \mathrm{~g}(\diamond), 0.5 \mathrm{~g}(\square)$, and $0.75 \mathrm{~g}(\Delta)$.

Discharge characteristics of GR cells do not appear to rely heavily on the quantity of $\mathrm{Zn}$ and display a more rapid discharge rate when compared to AB cells. Variable $\mathrm{Zn}-\mathrm{GR}$ cells are constructed in a similar manner to the variable $\mathrm{Zn}-\mathrm{AB}$ cells and display similar discharge characteristics to the initial Zn-GR primary cells. On construction OCVs are dependent on the quantity of $\mathrm{Zn}$. Above $0.5 \mathrm{~g} \mathrm{Zn}$ powder, it appears that the $\mathrm{OCV}$ is not affected when the $\mathrm{MnO}_{2}$ is held constant $(0.5 \mathrm{~g})$ and approaches $\sim 1.2 \mathrm{~V}$ (Figure 7). This can be attributed to the $\mathrm{MnO}_{2}$ being deficient for the cells that consisted of $\mathrm{Zn}$ above $0.5 \mathrm{~g}$. 


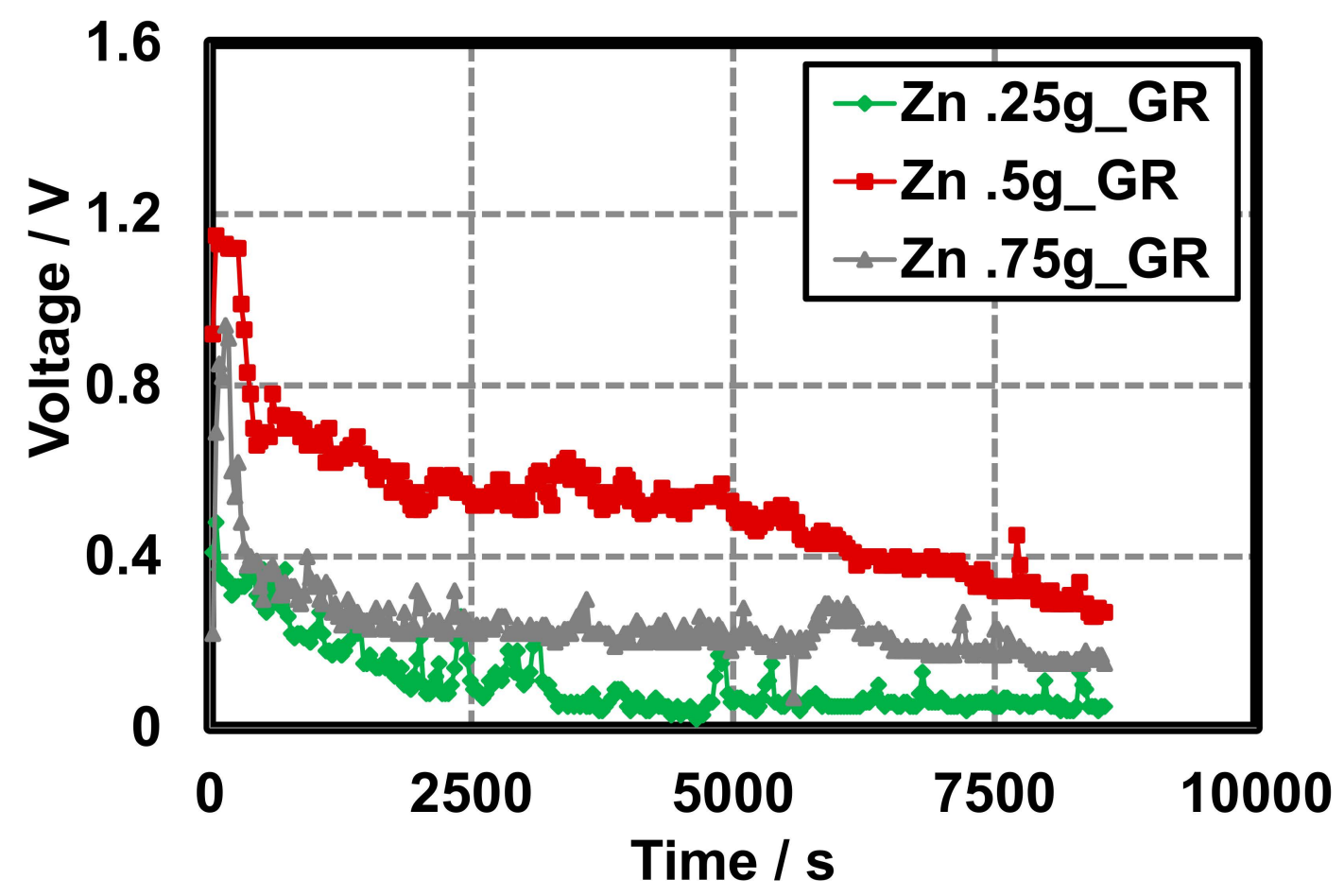

Figure 7. Gel Leclanché cell continuous discharge data across a $10 \mathrm{k} \Omega$ resistor with GR as the conductive additive, $0.5 \mathrm{~g} \mathrm{MnO}_{2}$, and variable zinc: $0.25 \mathrm{~g}(\bullet), 0.5 \mathrm{~g}(\square)$, and $0.75 \mathrm{~g}(\Delta)$.

The conductive additive also influences the energy density (Joules per liter or $\mathrm{JL}^{-1}$, total milli-ampere-hours or $\mathrm{mAh}$ ), and the coulombic capacity (ampere-hours or Ah) of cells constructed with different conductive additives. At $0.25 \mathrm{~g}$ zinc, cells with $\mathrm{AB}$ and GR have similar energy densities (AB 102.14 JL $\mathrm{JL}^{-1}$, GR 101.25 JL $\mathrm{JL}^{-1}$ ) (Figure 8).

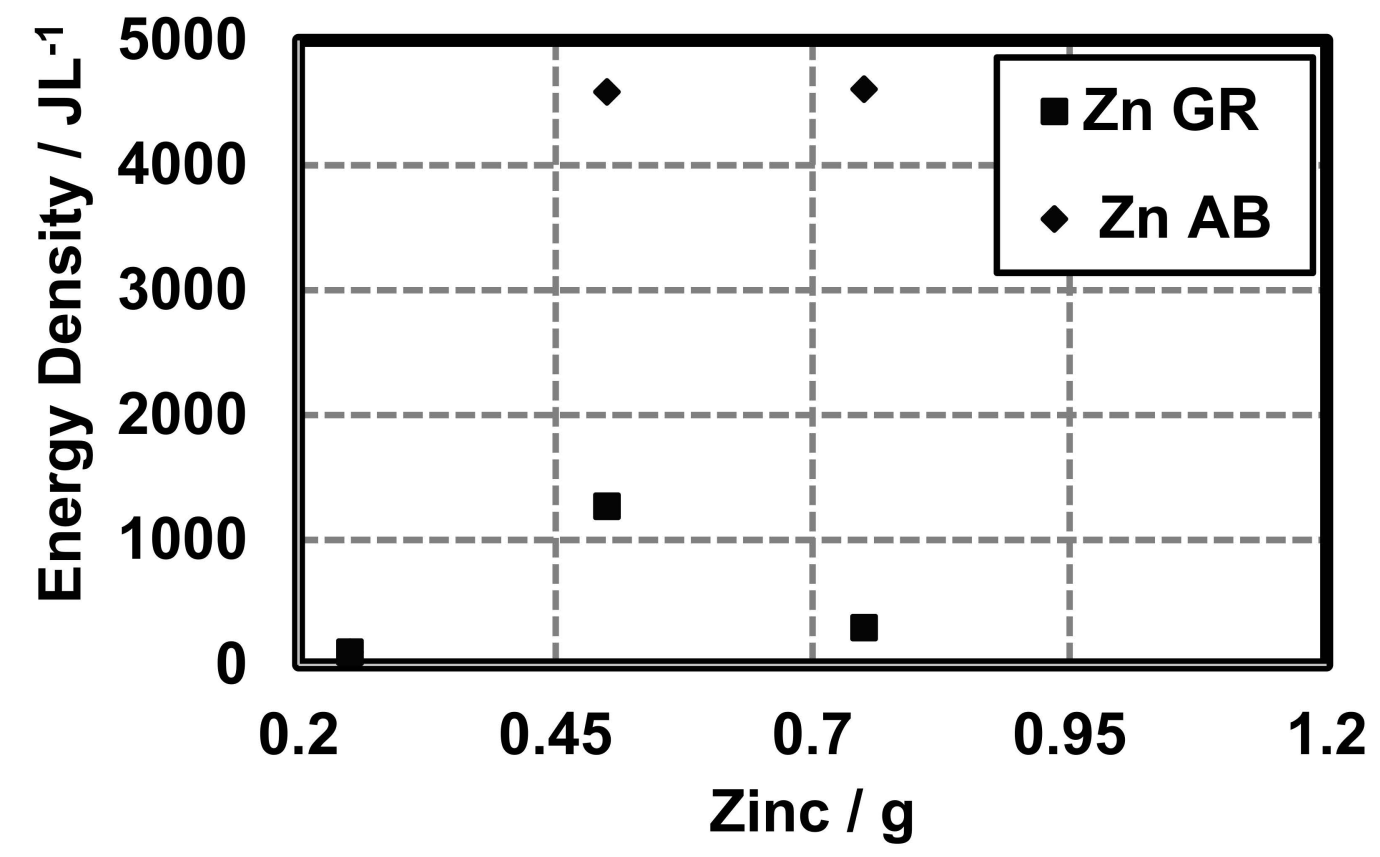

Figure 8. Energy density of cells made with variable amounts of zinc and different conductive additives (AB and GR). 
It must be noted that the coulombic capacity (mAh) of cells made with $0.25 \mathrm{~g}$ zinc and GR or AB is larger in cells made with GR (1.24 mAh) than cells made with AB (0.52 mAh). Total Ah was calculated for theoretical cells and compared to cells made with AB and GR at different quantities of $\mathrm{Zn}$ (Figure 9). Here, we show that the constructed cells are able to perform near $1 \%$ of their theoretical coulombic efficiency $\left(\eta_{c}\right)$, as defined by the theoretical coulombic capacity of the active material ( $\mathrm{Zn}$, $0.82 \mathrm{Ah} / \mathrm{g})[13]$ (Figure 10):

$$
\eta_{c}=\frac{\text { Discharge capacity }}{\text { Charge capacity }} \times 100
$$

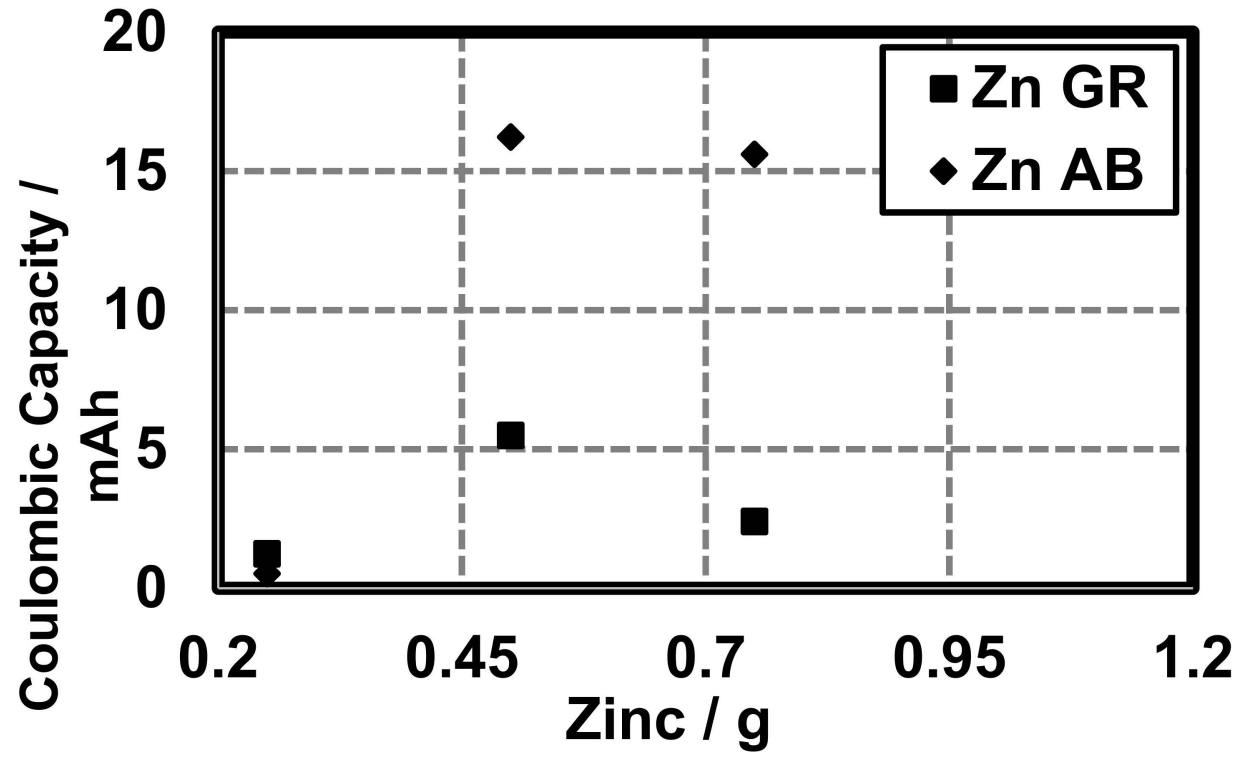

Figure 9. Coulombic capacity of cells made with variable amounts of zinc and different conductive additives (AB and GR).

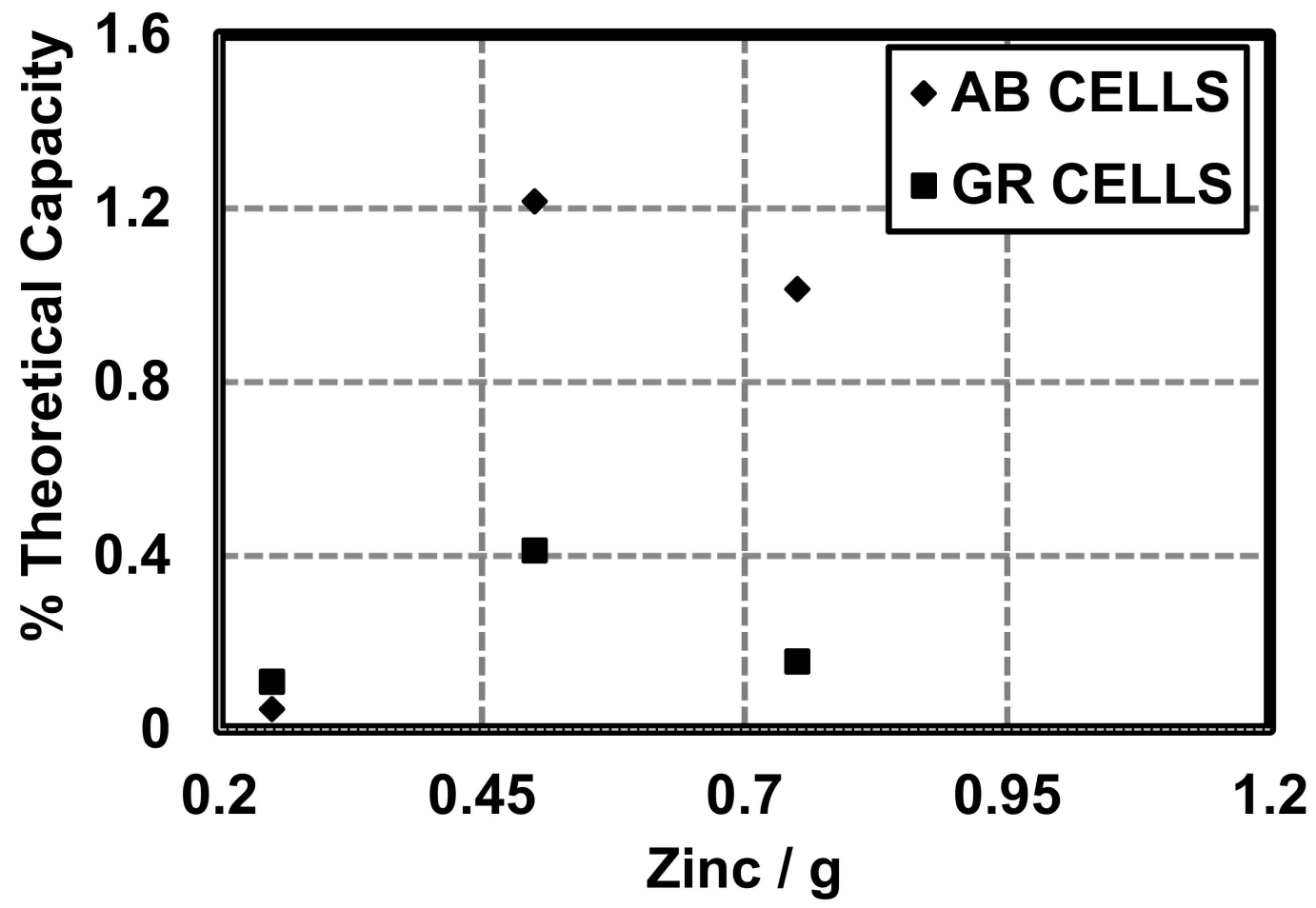

Figure 10. Coulombic efficiency as a \% of theoretical coulombic capacity. 


\subsection{Cell Purge and Refill}

This method exemplifies a purge and refill procedure of the cell. Upon construction, a potential of $0.15 \mathrm{~V}$ is observed, a peak potential is observed at $0.35 \mathrm{~V}$ after $125,000 \mathrm{~s}$, and a stabilized potential of $0.29 \mathrm{~V}$ is seen from 150,000 to $350,000 \mathrm{~s}$. At 400,000 s, the cell was purged and refilled and the potential again peaked a $0.28 \mathrm{~V}$ (Figure 11).

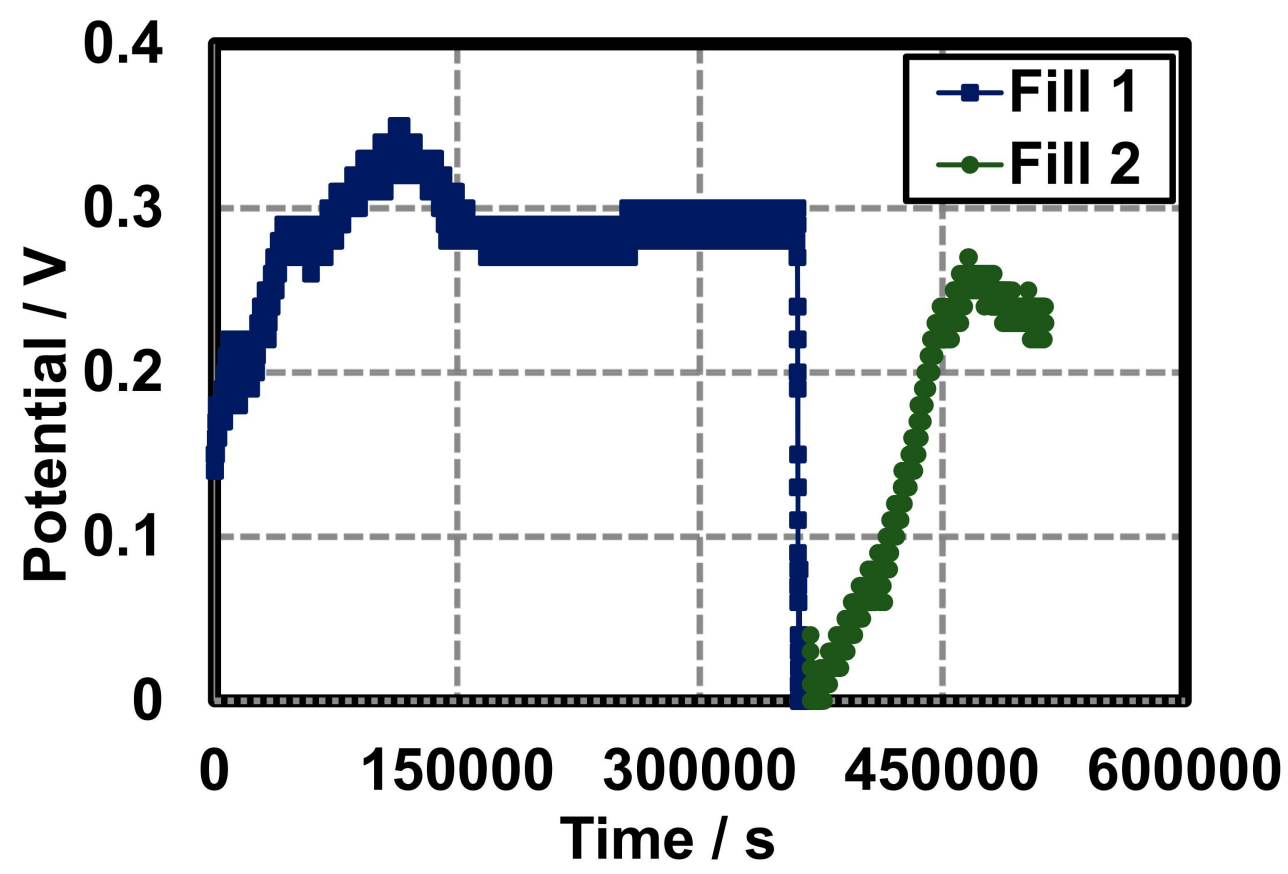

Figure 11. Fill and purge voltage of a closed gel Leclanché cell under $10 \mathrm{k} \Omega$ load with $\mathrm{AB}$ conductive additive. The cell was purged and refilled at 400,000 s.

\section{Discussion}

\subsection{General Discharge Characteristics}

Initially, the standard Leclanché chemistry was suspended in an aqueous agar hydrogel to explore the feasibility of the cell design and characterize the overall cell electrochemistry in order to display the reproducibility of the method (Figure 3). Subsequently, we designed a cell with better purging ability to test characteristics of variable amounts of active material (Figure 4). With this cell, the average open circuit voltage $(\mathrm{OCV})$ of three electrochemical cells on construction $(\sim 1.4 \mathrm{~V})$ was larger than initial closed-circuit voltage (CCV) $(\sim 0.75 \mathrm{~V})$ which is due to the electrochemical load imposed by the resistor. This resistor was chosen because it allowed the experiments to be conducted on a reasonable timeline that yielded data which compares some of the important battery components. Many battery standards use resistors in the ohm range, however in the interest of time our battery needed a larger resistor to generate complete discharge plots for each varied component [37].The general discharge characteristics displayed by the $\mathrm{Zn}$-graphite cells are similar to previous reports in the literature, however the timescales may differ depending on the load tested $[38,39]$.

When comparing our battery to commercially available batteries and other reports in the literature we find that the OCV general discharge trends are similar and that notable differences are obvious. Differences displayed by our batteries include high internal resistance (Mohm range) as compared to other systems that boast ohm range. We expect to optimize our hydrogel to decrease internal resistance and increase battery performance, as the clinical pacemaker needs to sustain a coulombic capacity near 1-2 Ah and accommodate resistances from 300 to $1000 \Omega$ [3,7]. Our energy density and coulombic efficiency is approximately $0.5 \%-1 \%$ of other reports. However, we have not saturated our hydrogel with active material and believe this will be improved upon in the near future [40,41]. Our batteries, 
which contain the same active chemicals as other zinc- $\mathrm{MnO}_{2}$ systems, are performing similar chemical reactions to those already established, however in a very different construction. We can be confident that our novel construction has not significantly altered the feasibility of this chemistry.

\subsection{Role of Active Material}

Variable zinc-GR cells are constructed in a similar manner to the variable $\mathrm{Zn}-\mathrm{AB}$ cells and display similar discharge characteristics to the initial zinc-GR primary cells of Figure 5. On construction, all cells irrespective of conductive additive, exhibit OCVs dependent on the quantity of Zinc. Beyond $0.5 \mathrm{~g}$ zinc powder, there is not a significant difference in the cell lifetime. However, increasing the $\mathrm{MnO}_{2}$ in combination with increasing zinc may deliver longer cell lifetimes (Figures 6 and 7). It has been previously reported that the specific sources of $\mathrm{MnO}_{2}$ can have a profound effect on the cell performance which will be further optimized [17,39].

Discharge characteristics of GR cells do not appear to rely heavily on the quantity of Zn and display a more rapid discharge rate when compared to $\mathrm{AB}$ cells. The terminal voltage appears to increase with the amount of $\mathrm{Zn}$ used in construction and is approached more gradually when compared to the $\mathrm{AB}$ cells. It must also be noted that the potential is more variable in GR-based cells than the AB-based cells.

\subsection{Role of Conductive Additive}

The ideal conductive additive should simply serve as a medium for electron transportation without influencing the chemical reactions of the cell. There are obvious trends in the OCV, CCV, discharge rates, energy density, and $\mathrm{mAh}$ depending on what conductive additive is used as previously noted.

AB-based cells display greater voltage stability and maintain higher voltage for a prolonged time. This suggests that $A B$ cells may better serve situations where higher voltage is required over greater time spans, while GR cells are better suited for rapid discharge over shorter time spans. It has previously been reported that the conductive additive can be used to tune Leclanché type cell discharge for specific applications and our data showcases the reproducibility of the agar-based system [42].

There is considerable literature reporting physical characteristics of conducting carbon powders when used in their compressed form and limited literature regarding their use in other specialized applications [43-46]. It is generally agreed that the particle size and size range, morphology, source and pressure used to compress powder influence the conductivity of the material and, in general, smaller and more tightly packed particles conduct electrons better [47-49]. The GR particles used were $<20 \mu \mathrm{m}$ in diameter and the $\mathrm{AB}$ particles were $25-45 \mathrm{~nm}$ in diameter (vendor sources). We suspect the considerably smaller size of $\mathrm{AB}$ particles is responsible for the greater electrical performance of cells by increasing the surface area available to the active materials, $\mathrm{Zn}$ and $\mathrm{MnO}_{2}$. Electrode composition was optimized for physical characteristics that would permit flow through a syringe to prevent clogging or separation. We acknowledge that the optimal electrode composition for physical characteristics and electrical characteristics may not coincide resulting in the large impedance. The role of mixing time, order, and identity of conductive additive all play a role in the electronic performance of the electrodes and will be investigated to optimized to limit the impedance of the battery [50-52]. Additionally, future studies cannot discount the influence of other physical characteristics such as adsorption, solubility and chemical structure of the conductive additive to influence the electrochemical performance of the cell.

The conductive additive also influences the energy density $\left(\mathrm{JL}^{-1}\right)$ coulombic capacity $(\mathrm{mAh})$ and the percent theoretical capacity of cells constructed with different conductive additives. However, the quantity of active material does not change and, therefore, theoretically, the energy density should remain the same. We observed differences in the energy density as a function of the conductive additive and quantity of zinc (Figure 8). As expected, the energy density increased with increasing zinc. However, the conductive additive also appears to influence the coulombic capacity (Figure 9). At $0.25 \mathrm{~g}$ zinc cells with $\mathrm{AB}$ and GR have similar energy densities (AB 102.14 $\mathrm{JL}^{-1}$, GR $101.25 \mathrm{JL}^{-1}$ ) 
(Figure 8). Beyond $0.5 \mathrm{~g}$ zinc the difference in energy densities between cells made with $A B$ and GR is large with cells made with $\mathrm{AB}$ being larger.

With regards to coulombic capacity, in cells constructed with variable quantities of zinc and either $\mathrm{AB}$ or $\mathrm{GR}$, a similar trend to energy density is observed-increasing zinc increases $\mathrm{mAh}$, with $\mathrm{AB}$ performing superior to GR at larger quantities of zinc (Figure 9). It must be noted that the coulombic capacity of cells made with $0.25 \mathrm{~g}$ zinc the trend is reversed. Further studies should be done to determine the validity of this finding. However, it may suggest that, for applications where the size of the battery must be extremely small, GR should be used as the conductive additive.

Theoretical capacity was calculated for theoretical cells and compared to cells made with $\mathrm{AB}$ and GR at different quantities of Zn (Figure 10). Theoretical coulombic efficiency is a way to relate the potential electrochemical energy of a material to the harvestable electrochemical energy of the system as reported by Linden and Reddy [13]. Here, we show that the constructed cells are able to perform near $1 \%$ of their theoretical coulombic capacity. It is well known that primary cells do not reach the theoretical coulombic capacity, but can be improved upon with different conductive additives, cell design, and separators.

\subsection{Purge and Refill}

To demonstrate the applicability of this method, a closed glass cell was constructed to record fill and purge voltage of gel Leclanché cell (Section 3.3). Ethylene glycol was added to make the purge and refill process easier. To our knowledge, this is the first method to explore a refillable hydrogel battery which demonstrates a novel method of electrochemical storage and conversion and could be used in medical implants or industrially scaled.

\section{Conclusions and Future Work}

The traditional chemistry of the Leclanché cell has been re-constructed in aqueous hydrogel for use in implantable medical devices or other hard access areas. In this work, the standard Leclanché chemistry has been suspended in agar hydrogel to immobilize the anode and cathode as to prevent spilling in addition to serving as the battery separator. These cells are easily constructed and utilize components (carbon electrode, glass vials, agar separators) that are inexpensive and common in many research laboratories. Construction of these fuel cells in a single vial exemplifies the feasibility of this method for hard to access applications, such as a pacemaker. These implantable cells will be tuned to increase cell lifetime, voltage and discharge characteristics that meet the energetic demands of a specific device. The role of the conductive additive plays a significant role in cell potential in addition to the discharge characteristics and will be exploited to suit particular energy demands. The method of fabrication may affect the mechanical stability of the hydrogel as well as the electronic performance and will be the subject of future investigations Fine tuning the removal and reconstruction of the spent hydrogel electrode is being refined. Future work will also include better characterization of cell impedance, as well as use of a potentiostat to carry out more characterization. As the work develops further, a lower discharge resistance will also have to be tested to better understand practical applications of this battery. This data highlights the potential of this methodology as a technically simplify the procedure to replace exhausted electroactive material in devices where access is limited.

Author Contributions: Conceptualization, G.J., G.S., A.R. and J.K.B.; methodology, G.J. and G.S.; software, G.S.; validation, G.J., G.S. and A.R.; formal analysis, G.J.; investigation, G.J.; resources, G.J.; data curation, G.J.; writing_original draft preparation, G.J. and G.S.; writing—review and editing, G.J. and G.S.; visualization, G.J. and G.S.; supervision, A.R. and J.K.B.; project administration, A.R. and J.B.; funding acquisition, A.R. and J.K.B. All authors have read and agreed to the published version of the manuscript.

Funding: This research is funded, in part, by the Mid-America Transportation Center via a grant from the U.S. Department of Transportation's University Transportation Centers Program, and this support is gratefully acknowledged. The contents reflect the views of the authors, who are responsible for the facts and the accuracy of the information presented herein, and are not necessarily representative of the sponsoring agencies, organizations or persons. 
Acknowledgments: The authors would like to acknowledge Ronald Weigel, Head of Department of Surgery and Professor of Biochemistry at The University of Iowa, for his support in securing lab space and providing financial assistance. This support has been instrumental in making this research a reality. The contents reflect the views of the authors, who are responsible for the facts and the accuracy of the information presented herein, and are not necessarily representative of the sponsoring agencies, organizations or persons.

Conflicts of Interest: The authors declare no conflict of interest.

\section{References}

1. Nicholls, M. Pioneers of cardiology: Rune Elmqvist, MD. Circulation 2007, 115. [CrossRef]

2. Greatbatch, W. Origins of the implantable cardiac pacemaker. J. Cardiovasc. Nurs. 1991, 5, 80-85. [PubMed]

3. Deforge, W. Cardiac pacemakers: A basic review of the history and current technology. J. Veter Cardiol. 2019, 22, 40-50. [CrossRef] [PubMed]

4. Mallela, V.S.; Ilankumaran, V.; Rao, N.S. Trends in Cardiac Pacemaker Batteries. Indian Pacing Electrophysiol. J. 2004, 4, 201-212. [PubMed]

5. Kotsakou, M.; Kioumis, I.; Lazaridis, G.; Pitsiou, G.; Lampaki, S.; Papaiwannou, A.; Karavergou, A.; Tsakiridis, K.; Katsikogiannis, N.; Karapantzos, I.; et al. Pacemaker insertion. Ann. Transl. Med. 2015, 3, 42. [CrossRef]

6. Kindermann, M.; Schwaab, B.; Berg, M.; Frohlig, G. Longevity of dual chamber pacemakers: Device and patient related determinants. Pacing Clin. Electrophysiol. 2001, 24, 810-815. [CrossRef]

7. Mond, H.G.; Freitag, G. The Cardiac Implantable Electronic Device Power Source: Evolution and Revolution. Pacing Clin. Electrophysiol. 2014, 37, 1728-1745. [CrossRef]

8. Leclanché, G. Notes sur l'emploi des piles électriques en télégraphie, pile constante au peroxyde de manganeèse à un seul liquide; Impr. de Hennuyer et fils: Paris, France, 1867.

9. Larcin, J. Chemical and Electrochemical Studies of Leclanché Cells. Ph.D. Thesis, Middlesex University, London, UK, 1991.

10. Stimming, U.; Bele, P. Fuel Cells-Lots of Energy for 2016. Fuel Cells 2016, 16, 2. [CrossRef]

11. Stimming, U.; Bele, P. Further Ahead with Electrochemical Energy Technology. Fuel Cells 2017, 17, 2. [CrossRef]

12. Stimming, U.; Bele, P. Fuel Cells in a Changing Energy World. Fuel Cells 2018, 18, 3. [CrossRef]

13. Linden, D.; Reddy, T.B. Linden's Handbook of Batteries; McGraw-Hill: New York, NY, USA, 2001.

14. Guo, Y.-G. Nanostructures and Nanomaterials for Batteries; Springer Science and Business Media: Berlin/Heidelberg, Germany, 2019.

15. Khalid, N.; Ismail, Y.B.; Mohamad, A.A. $\mathrm{ZnCl}_{2}{ }^{-}$and $\mathrm{NH}_{4} \mathrm{Cl}^{-}$hydroponics gel electrolytes for zinc-carbon batteries. J. Power Sources 2008, 176, 393-395. [CrossRef]

16. An, L.; Zhao, T.; Zhou, X.; Yan, X.; Jung, C. A low-cost, high-performance zinc-hydrogen peroxide fuel cell. J. Power Sources 2015, 275, 831-834. [CrossRef]

17. Li, G.; Mezaal, M.A.; Zhang, R.; Zhang, K.; Lei, L. Electrochemical Performance of MnO2-based Air Cathodes for Zinc-air Batteries. Fuel Cells 2016, 16, 395-400. [CrossRef]

18. Jensen, W.B. The Leclanché Cell. Notes from the Oesper Collections; University of Cincinnati: Cincinnati, OH, USA, 2014; Available online: http://www.che.uc.edu/jensen/W.\%20B.\%20Jensen/Museum\%20Notes/24. \%20The\%20Leclanch\%C3\%A9\%20Cell.pdf.

19. Jenson, G.; Singh, G.; Bhama, J.K.; Ratner, A. A refillable hyrdogel battery: Construction and characterization. J. Energy Storage 2019, 23, 504-510. [CrossRef]

20. Ahmed, E.M. Hydrogel: Preparation, characterization, and applications: A review. J. Adv. Res. 2013, 6, 105-121. [CrossRef]

21. Zhang, X.; Kim, G.J.; Kang, M.G.; Lee, J.K.; Seo, J.W.; Tae, J.; Hong, K.; Cha, J.M.; Shin, S.R.; Bae, H. Marine Biomaterial-Based Bioinks for Generating 3D Printed Tissue Constructs. Mar. Drugs 2018, 16, 484. [CrossRef]

22. Basu, P.; Saha, N.; Alexandrova, R.; Andonova-Lilova, B.; Georgieva, M.; Miloshev, G.; Saha, P. Biocompatibility and Biological Efficiency of Inorganic Calcium Filled Bacterial Cellulose Based Hydrogel Scaffolds for Bone Bioengineering. Int. J. Mol. Sci. 2018, 19, 3980. [CrossRef] [PubMed]

23. Ahmad, N.; Colak, B.; Gibbs, M.J.; Zhang, D.-W.; Becer, C.R.; Watkinson, M.; Gautrot, J.E.; Krause, S. Collagenase Biosensor Based on the Degradation of Peptide Cross-Linked Poly(Ethylene Glycol) Hydrogel Films. Proceedings 2018, 2, 961. [CrossRef] 
24. Mittmann, E.; Gallus, S.; Bitterwolf, P.; Oelschlaeger, C.; Willenbacher, N.; Niemeyer, C.M.; Rabe, K.S. A Phenolic Acid Decarboxylase-Based All-Enzyme Hydrogel for Flow Reactor Technology. Micromachines 2019, 10, 795. [CrossRef]

25. González-Martínez, A.; De Simón-Martín, M.; López, R.; Táboas-Fernández, R.; Bernardo-Sánchez, A. Remediation of Potential Toxic Elements from Wastes and Soils: Analysis and Energy Prospects. Sustainability 2019, 11, 3307. [CrossRef]

26. Lu, J.; Zhang, X.; Gao, H.; Cui, W. Three-Dimensional Structure of PANI/CdS NRs-SiO 2 Hydrogel for Photocatalytic Hydrogen Evolution with High Activity and Stability. Nanomaterials 2019, 9, 427. [CrossRef] [PubMed]

27. Singh, R.; Veer, B. Hydrogels: Promising Energy Storage Materials. ChemistrySelect 2018, 3, $1309-1320$. [CrossRef]

28. Crulhas, B.R.; Ramos, N.P.; Basso, C.R.; Costa, V.E.; Castro, G.R.; Pedrosa, V.A. Fabrication and Characterization of Ferrocenece Containing Hydrogel for Glucose Biosensor Application. Int. J. Electrochem. Sci. 2014, 9, 7596-7604.

29. Chen, M.; College of Chemistry and Environmental Engineering, Yangtze University. Microporous N-doped Carbon Electrochemical Catalyst Derived from Polyacrylamide Hydrogel for Oxygen Reduction Reaction in Alkaline Media. Int. J. Electrochem. Sci. 2018, 13, 2401-2411. [CrossRef]

30. Rosi, M.; Iskandar, F.; Abdullah, M. Hydrogel-polymer electrolytes based on polyvinyl alcohol and hydroxyethylcellulose for supercapacitor applications. Int. J. Electrochem. Sci. 2014, 9, 4251-4256.

31. Marliana, Y.; Ismail, B.; Haliman, H.; Mohamad, A.A. Hydroponics Polymer Gels for Zn- $\mathrm{MnO}_{2}$ Alkaline Batteries. Int. J. Electrochem. Sci. 2012, 7, 3555-3566.

32. Mainar, A.R.; Iruin, E.; Colmenares, L.C.; Kvasha, A.; De Meatza, I.; Bengoechea, M.; Leonet, O.; Boyano, I.; Zhang, Z.; Blázquez, J.A. An overview of progress in electrolytes for secondary zinc-air batteries and other storage systems based on zinc. J. Energy Storage 2018, 15, 304-328. [CrossRef]

33. Kim, J.-M.; Yoo, S.; Lim, J.-M.; Park, S.; Lee, S.-Y. Agarose-biofunctionalized, dual-electrospun heteronanofiber mats: Toward metal-ion chelating battery separator membranes. J. Mater. Chem. A 2015, 3, 10687-10692. [CrossRef]

34. Armisen, R.; Galatas, F. Production and Utilization of Products from Commercial Seaweeds; McHugh, D.J., Ed.; FAO Fisheries Technical Report; FAO Fisheries: Rome, Italy, 1987.

35. Arduino Reference. Available online: https://www.arduino.cc/ (accessed on 7 May 2019).

36. Hawley, W.B.; Li, J. Electrode manufacturing for lithium-ion batteries-Analysis of current and next generation processing. J. Energy Storage 2019, 25. [CrossRef]

37. American National Standard for Portable Primary Cells and Batteries with Aqueous Electrolyte-General and Specifications. Available online: https:/www.batterybob.com/Battery-Reference/ansi_c18_1part1.pdf. (accessed on 22 January 2020).

38. Rogulski, Z.; Czerwiński, A. Cathode modification in the Leclanché cell. J. Solid State Electrochem. 2003, 7, 118-121. [CrossRef]

39. Bockris, J.O.; Conway, B.E.; Yeager, E.; White, R.E. Electrochemical Processing. In Comprehensive Treatise of Electrochemistry; Springer: Berlin/Heidelberg, Germany, 1981.

40. Alkaline Manganese Dioxide Handbook and Application Manual, Energizer LLC. 2018. Available online: https://data.energizer.com/pdfs/alkaline_appman.pdf (accessed on 22 January 2020).

41. Ghiurcan, G.A.; Liu, C.-C.; Webber, A.; Feddrix, F.H. Development and Characterization of a Thick-Film Printed Zinc-Alkaline Battery. J. Electrochem. Soc. 2003, 150, A922-A927. [CrossRef]

42. Benson, G.; Gluck, J.; Kaufmann, C. Electrical Conductivity Measurements of Carbon Blacks. Trans. Electrochem. Soc. 1946, 90, 441. [CrossRef]

43. Sebok, E.; Taylor, R.L. Carbon blacks. Encycl. Mater. Sci. Technol. 2001, 902-906. [CrossRef]

44. Singh, G.; Esmaeilpour, M.; Ratner, A. The effect of acetylene black on droplet combustion and flame regime of petrodiesel and soy biodiesel. Fuel 2019, 246, 108-116. [CrossRef]

45. Singh, G.; Lopes, E.; Hentges, N.; Becker, D.; Ratner, A. Experimental Investigation of the Settling Characteristics of Carbon and Metal Oxide Nanofuels. J. Nanofluids 2019, 8, 1-7. [CrossRef]

46. Singh, G.; Esmaeilpour, M.; Ratner, A. Effect of carbon-based nanoparticles on the ignition, combustion and flame characteristics of crude oil droplets. arXiv 2019, arXiv:1910.12135. 
47. Celzard, A.; Marêché, J.; Payot, F.; Furdin, G. Electrical conductivity of carbonaceous powders. Carbon 2002, 40, 2801-2815. [CrossRef]

48. Zhang, X.; Cui, Y.; Lv, Z.; Li, M.; Ma, S.; Cui, Z.; Kong, Q. Carbon nanotubes, Conductive Carbon Black and Graphite Powder Based Paste Electrodes. Int. J. Electrochem. Sci. 2011, 6, 6063-6073.

49. Marinho, B.; Ghislandi, M.; Tkalya, E.; Koning, C.E.; De With, G. Electrical conductivity of compacts of graphene, multi-wall carbon nanotubes, carbon black, and graphite powder. Powder Technol. 2012, 221, 351-358. [CrossRef]

50. Du, Z.; Li, J.; Wood, M.; Mao, C.; Daniel, C.; Wood, D. Three-dimensional conductive network formed by carbon nanotubes in aqueous processed NMC electrode. Electrochim. Acta 2018, 270, 54-61. [CrossRef]

51. Tsai, H.-L.; Hsieh, C.-T.; Li, J.; Gandomi, Y.A. Enabling high rate charge and discharge capability, low internal resistance, and excellent cycleability for Li-ion batteries utilizing graphene additives. Electrochim. Acta 2018, 273, 200-207. [CrossRef]

52. Li, J.; Armstrong, B.L.; Daniel, C.; Kiggans, J.; Wood, D.L.; Kiggans, J. Optimization of multicomponent aqueous suspensions of lithium iron phosphate $\left(\mathrm{LiFePO}_{4}\right)$ nanoparticles and carbon black for lithium-ion battery cathodes. J. Colloid Interface Sci. 2013, 405, 118-124. [CrossRef] [PubMed]

(C) 2020 by the authors. Licensee MDPI, Basel, Switzerland. This article is an open access article distributed under the terms and conditions of the Creative Commons Attribution (CC BY) license (http://creativecommons.org/licenses/by/4.0/). 